\title{
VARIABEL-VARIABEL YANG MEMPENGARUHI KEPUASAN DAN KEPUTUSAN PEMBELIAN ULANG PADA KOPI MADE
}

\author{
Variables that Affect Satisfaction and \\ Purchase Decision Kopi Made
}

\section{Nengah Ari Medikana, I Nyoman Gede Ustriyana, IGA Oka Suryawardani}

\author{
Program Studi Magister Agribisnis, Fakultas Pertanian, Universitas Udayana, Bali, Indonesia
}

Email : arimedikanal@gmail.com

\begin{abstract}
The number of coffee shops in Denpasar City trigger the existence of competition. One of the coffee shops in Denpasar City is Kopi Made. The purpose of this study is to analyze the level of customer satisfaction, the influence of coffee shop conditions, product quality, and quality of service to customer satisfaction and the influence of customer satisfaction on purchasing decision. The location of this study was at Kopi Made and determined by puposive. The population was the visitors who make a purchase more than one. The sampling technique was convenience sampling. Number of samples was taken as many as 100 samples. This research used customer satisfaction index (CSI), inportant performance analysis (IPA), and partial least squares (PLS). The results showed that customer satisfaction index (CSI) of Kopi Made in the category very satisfied with the value 82.79\%. Important Performance Analysis (IPA) showed four attributes that need to be improved, including product variation, product innovation development, benefits after consuming products, and physical cleanliness of Kopi Made. In addition, the results of the study also showed that atmosphere of Kopi Made, product quality, and service quality significantly affect customer satisfaction. Atmosphere of Kopi Made gave the highest influence on customer satisfaction that was equal to 0.389. Furthermore, customer satisfaction also has a significant influence on customer purchasing decisions. Customer satisfaction gave the effect of 0,593.
\end{abstract}

Keywords: Kopi Made, Customer Satisfaction, Purchase Decision.

\begin{abstract}
ABSTRAK
Banyaknya warung kopi di Kota Denpasar memicu adanya persaingan. Salah satu kedai kopi di Kota Denpasar adalah Kopi Made. Tujuan dari penelitian ini adalah untuk menganalisis tingkat kepuasan pelanggan, pengaruh kondisi coffee shop, kualitas produk, dan kualitas layanan terhadap kepuasan pelanggan dan pengaruh kepuasan pelanggan terhadap keputusan pembelian. Lokasi penelitian ini adalah di Kopi Made dan ditentukan secara puposive. Populasi adalah pengunjung yang melakukan pembelian lebih dari satu. Teknik pengambilan sampel adalah convenience sampling. Jumlah sampel yang diambil sebanyak 100 sampel. Penelitian ini menggunakan indeks kepuasan pelanggan (CSI), inportant performance analysis (IPA), dan partial least square (PLS). Hasil penelitian menunjukkan bahwa indeks kepuasan pelanggan (CSI) Kopi Made dalam kategori sangat puas dengan nilai $82,79 \%$. Analisis Kinerja Penting (IPA) menunjukkan empat atribut yang perlu ditingkatkan, termasuk variasi produk, pengembangan inovasi produk, manfaat setelah mengonsumsi produk, dan kebersihan fisik Kopi Made. Selain itu, hasil penelitian juga menunjukkan bahwa suasana Kopi Made, kualitas produk, dan kualitas layanan secara signifikan mempengaruhi kepuasan pelanggan. Suasana Kopi Made memberikan pengaruh tertinggi terhadap kepuasan pelanggan yaitu sebesar 0,389. Selanjutnya, kepuasan pelanggan juga memiliki pengaruh yang signifikan terhadap keputusan pembelian pelanggan. Kepuasan pelanggan memberikan efek 0,593.
\end{abstract}

Kata kunci: Kopi Made, Kepuasan Pelanggan, Keputusan Pembelian.

\section{PENDAHULUAN}

\section{Latar Belakang}

Persaingan antar perusahaan atau bisnis sangat penting untuk dianalisis untuk memahani cara menciptakan kepuasan konsumen termasuk bisnis di bidang coffee shop. Khususnya di Kota Denpasar, keberadaan Coffee Shop mulai menjamur dan tersebar di beberapa wilayah. Masyarakat perkotaan dengan gaya hidup kosmopolitan memilih menghabiskan sebagian sumberdaya yang mereka miliki berupa uang, waktu, dan perhatian yang menjadi cerminan gaya hidup dengan mengkonsumsi makanan dan minuman coffee shop ternama. Salah satu coffee shop yang dikunjungi adalah Kopi Made. Berbagai coffee shop yang ada dengan berbagai macam penawaran menyebabkan beragamnya alternatif pilihan bagi konsumen yang memicu adanya persaingan. Hal ini menjadi tantangan bagi Kopi Made dalam memenangkan persaingan dalam menjaga serta menarik pelanggan baru. Menyenangkan pelanggan dapat dilakukan dengan menyiasati suasana toko (store atmosphere), 
menciptakan produk yang berkualitas, dan kualitas pelayanan pada coffee shop tersebut.

\section{Tujuan Penelitian}

Tujuan penelitian ini adalah menganalisis tingkat kepuasan konsumen Kopi Made serta menganalisis pengaruh variabel karakteristik konsumen, suasana Kopi Made, kualitas produk, dan kualitas pelayanan terhadap kepuasan konsumen dan pengaruh kepuasan konsumen terhadap keputusan pembelian ulang oleh konsumen Kopi Made.

\section{Penelitian Sebelumnya}

Suryawardani dan Wiranatha (2016) melakukan penelitian tentang Assessment of Gusets' Perception in Implementation of Green Tourism in Supporting Sustainable Tourism in a Hotel in Bali. Hasil penelitian menunjukkan bahwa penilaian wisatawan yang menginap di hotel tersebut memberikan penilaian yang positip terhadap pelaksanaan konsep green hotel dalam operasional hotel yang meliputi konservasi terhadap lingkungan di hotel, pelestarian sosial budaya yang berdampak terhadap peningkatan ekonomi dan kesejahteraan karyawan hotel. Perhatian pengelola hotel terhadap pelestarian lingkungan dalam operasional hotel diimplementasikan melalui efisiensi dalam pemanfaatan energi dan sumber daya air, sedangkan pengelolaan limbah hotel diimplementasikan melalui penerapan konsep reuse dan recycle. Kepedulian hotel terhadap kontribusinya terhadap masyarakat diimplementasikan melalui program CSR (Corporate Social Responsibily).

Wiranatha (2015) dalam penelitiannya tentang Sustainable Development Strategy for Ecotourismat Tangkahan North Sumatra. Hasil penelitian menunjukkan bahwa strategi dalam pengembangan ekowisata adalah: (i) menjaga klestarian flora dan fauna, (ii) mengembangkan wisata alam dengan mengedepankan prinsip-prinsip ekowisata dan pelestarian alam mengedepankan prinsip-prinsip ekowisata dan pelestarian alam, (iii) mengedepankan keselamatan pengunjung dan pemandu wisata yang sedang melakukan aktivitas wisata, (iv) merevotalisasi music dan tarian tradisional, (v) memperluas trekking yang sudah ada di destinasi Tangkahan, (vi) meningkatkan jumlah gajah dan (vii) meningkatkan vasilitas akomodasi tanpa merusak lingkungan, (viii) mengembangkan transportasi darat menuju lokasi atraksi wisata, meningkatkan fasilitas dan infrastruktur pendukung aktivitas wisata seperti perbankan, toilet umum dan pengelolaan areal parkir yang terintegrasi, meningkatkan fasilitas listrik dan jejaring di pusat atraksi wisata Tangkahan.

Pramono et.al. (2016) dalam penelitiannya tentang Environmental Management at Star Rated hotel in Bali. Hasil penelitian menunjukkan bahwa terdapat hubungan yang signifikan antara isu-isu lingkungan, pengelolaan lingkungan dan manfaat pengelolaan lingkungan pada hotel berbintang di Bali.

Hasil penelitian Suryawardani (2018) tentang Evaluation of Marketing Strategy of Sanur Village
Festival Baesd on Visitors' Behaviour dengan pendekatan The Theory of Planned Behaviour dan dianalisis dengan Smart-PLS menyimpulkan (i) bahwa niat berkunjung secara signifikan dipengaruhi oleh attitudes towards behaviour dan perceived behaviour control, (ii) Plan to revisit (actual behaviour) secara signifikan dipengaruhi oleh behavioural intention dan perceived behaviour control (iii) Hubungan secara signifikan antara intention to visit and plan to visit Sanur Village Festival tahun berikutnya, dan (iv) komunikasi pemasaran secara terintegrasi sudah diterapkan pada even seni budaya yang sangat bergengsi dalam rangka membangkitkan kembali pariwisata Bali setelah terpuruk akibat berbagai kejadian terorisme yang sangat merugikan.

Suryawardani, et.al. (2017) dalam penelitiannya tentang A Structural Model of Foreign Tourists' Loyalty in Nature-based Tourism in Bali menemukan bahwa motivasi intrinsik dan ekstrinsik berpengaruh secara signifikan terhadap loyalitas wisatawan asing mengunjungi wisata alam yang dimediasi oleh kepuasan wisatawan. Peningkatan kualitas destinasi sangat diperlukan sebagai daya dukung keberhasilan atraksi wisata alam di Bali

Hasil penelitian Wiranatha, et.al. (2018) tentang Model of Foreign Tourists's Loyalty on Marine Tourism to Visit Bali menemukan bahwa: (i) Motivasi intrinstik berpengaruh signifikan terhadap kepercayaan wisatawan (trust) dalam melakukan aktivitas menyelam (diving), (ii) Motivasi ektrinsik berpengaruh signifikan terhadap kepuasan (satisfaction), dan (iii) Kepuasan wisatawan dalam melaksanakan aktivitas menyelam berpengaruh positip terhadap loyalitasnya dalam melakukan aktivitas selanjutnya.

Hasil penelitian Wiranatha, et. al. (2018) tentang Model of Foreign Tourists' Loyalty in Cultural and Heritage Tourism in Bali menyimpulkan bahwa wisatawan asing sangat puas dalam mengunjungi situs warisan budaya Bali. Variabel yang mempengaruhi kepuasan wisatawan dalam mengunjungi situs warisan budaya Bali adalah motivasi intrinsik, ektrinsik dan kepercayaan. Berdasarkan efek langsung, hasil penelitian menunjukkan bahwa hubungan secara signifikan ditemukan pada variabel motivasi intrinsik dengan kepercayaan, motivasi ektrinsik dengan kepuasan, dan hubungan antara kepercayaan dengan kepuasan, namun hubungan secara signifikan tidak detemukan pada variabel intrinsik dengan kepuasan. Berdasarkan efek tidak langsung, hubungan secara signifikan terjadi antara motivasi intrinsik dan loyalitas melalui mediasi kepercayaan. Hasil penelitian mengindikasikan bahwa reputasi pariwisata Bali sebagai destinasi warisan budaya sangat diminati oleh wisatawan asing. Oleh karena itu kelestarian budaya Bali perlu dijaga.

Penelitian dalam pemasaran yang dilakukan oleh Suryawardani dan Wiranatha (2015) tentang Destination Marketing Strategy in Bali through Optimizing the Potential of Local Products meyimpulan bahwa strategi pemasaran sebuah Medikana, et al., Variabel..|32 
destinasi wajib mengedepankan optimimalisasi of daya saing produk-produk lokal. Bentang alam yang indah dan keindahan alam yang menakjubkan yang dimiliki oleh Bali menjadi daya dukung suksesnya atraksi wisata alam yang ada di Bali.

Penelitian yang dilakukan oleh Sutrisno dan Ustriyana (2015) tentang Urban Development and Its Impact On Agriculture Lands menyimpulkan bahwa Konversi lahan pertanian mungkin berdampak pada ketersediaan stok makanan, peningkatan moneter untuk makanan impor, penurunan pendapatan petani lokal, peningkatan kebutuhan tenaga kerja di sektor lain selain pertanian dan mengurangi semangat orang untuk bekerja di sektor pertanian.

Penelitian yang dilakukan oleh Ustriyana (2016) tentang Factors Shaping the Image of Badung Traditional Market in Denpasar City, Bali Province menyimpulkan bahwa terdapat enam faktor pembentuk citra Pasar Tradisional Badung, yaitu harga, pelayanan, kualitas, lingkungan fisik, lokasi dan keragaman produk.

\section{METODE PENELITIAN}

\section{Lokasi dan Waktu Penelitian}

Penelitian dilaksanakan di Kopi Made yang berada di Jalan Raya Pututan, Renon, Denpasar. Pemilihan lokasi penelitian ditentukan dengan cara sengaja (purposive) dengan pertimbangan Kopi Made berada di lokasi dengan keberadaan coffee shop paling banyak di Kota Denpasar. Penelitian dilakukan pada bulan November 2017 s.d. Januari 2018.

\section{Populasi dan Sampel}

Populasi dalam penelitian ini adalah masyarakat yang sudah pernah membeli produk di Kopi Made lebih dari satu kali. Pengambilan sampel ditentukan dengan metode convenience sampling. Jumlah sampel dalam penelitian ini ditetapkan secara purposive yaitu sebesar 100 orang responden.

\section{Variabel Penelitian}

Variabel-variabel yang digunakan dalam penelitian ini, meliputi (i) karakteristik konsumen dengan indikator umur, pendidikan, posisi dalam pekerjaan, dan pendapatan, (ii) suasana Kopi Made dengan indikator bagian luar, bagian dalam, tata letak, dan pemajangan informasi, (iii) kualitas Produk dengan indikator kinerja, fitur, kesesuaian, keindahan, dan persepsi kualitas, (iv) kualitas pelayanan dengan indikator bukti fisik, kehandalan, daya tanggap, empati, dan jaminan, (v) kepuasan konsumen dengan indikator senang/puas terhadap suasana Kopi Made, senang/puas terhadap produk, senang/puas terhadap pelayanan, dan kesesuaian dengan harapan, dan (vi) keputusan pembelian ulang dengan indikator enggan berpindah ke coffee shop lain, merekomendasikan kepada pihak lain, membuat ingin menambah pesanan, dan membuat ingin berkunjung kembali.

\section{Metode Analisis Data}

Semua indikator dan parameter dari variabel penelitian diukur dengan skala lima, yaitu dari skor 1 - 5. Setelah memperoleh data, maka data dianalisis dengan alat analisis sebagai berikut.

1. Customer Satisfaction Index (CSI),

CSI merupakan alat analisis untuk menjawab tujuan penelitian pertama. Langkah-langkah dalam melakukan analisis CSI adalah sebagai barikut (Stratford dalam Supranto (2001).

(1) Menghitung Weighting Factor (WF), yaitu mengubah nilai rataan kepentingan menjadi angka persentase dari total rataan tingkat kepentingan seluruh atribut yang diuji, sehingga didapatkan total WF $100 \%$.

(2) Menghitung Weighted Score (WS), yaitu nilai perkalian antara nilai rataan tingkat kinerja (kepuasan) masing-masing atribut dengan WF masing-masing atribut.

(3) Menghitung Weighted total (WT), yaitu menjumlahkan WS dari semua atribut.

(4) Menghitung Satisfaction Index, yaitu WT dibagi skala maksimal yang digunakan (dalam penelitian ini skala maksimal adalah 5), kemudian dikali $100 \%$

Berikut ini merupakan rentang nilai CSI yang ditunjukkan pada Tabel 1

Tabel 1. Rentang Nilai Customer Satisfaction Index

\begin{tabular}{cc}
\hline Rentang Nilai & Kategori \\
\hline $0,81-1,00$ & Sangat Puas \\
$0,65-0,80$ & Puas \\
$0,50-0,64$ & Netral \\
$0,34-0,50$ & Tidak Puas \\
$0,01-0,34$ & Sangat Tidak Puas \\
\hline
\end{tabular}

2. Important Performance Analysis (IPA) IPA merupakan alat analisis untuk melengkapi hasil CSI. Langkah-langkah dalam melakukan analisis IPA adalah sebagai berikut.

(1) Menghitung rata-rata tingkat kepentingan dan tingkat kepuasan untuk setiap item dari atribut dengan rumus:

$$
\begin{gathered}
\bar{X}_{i}=\frac{\sum_{i=1}^{k} x_{i}}{n} \\
\bar{Y}_{i}=\frac{\sum_{i=1}^{k} y_{i}}{n}
\end{gathered}
$$


Keterngan :

$\mathrm{Xi}=$ Bobot rata-rata tingkat kepuasan item ke-i

$\mathrm{Yi}=$ Bobot rata-rata tingkat kepentingan item ke-i

$\mathrm{n}=$ jumlah responden/sampel

(2) Menghitung rata-rata tingkat kepentingan dan tingkat kepuasan untuk keseluruhan item dengan rumus:

$$
\overline{\bar{x}_{i}}=\frac{\sum_{i=1}^{k} \bar{x}_{i}}{p}
$$

$$
\overline{\bar{y}_{i}}=\frac{\sum_{i=1}^{k} \bar{y}_{i}}{p}
$$

Keterangan :

$\mathrm{Xi}=$ Nilai rata-rata kepuasan item

$\mathrm{Yi}=$ Nilai rata-rata kepentingan item $\mathrm{p}=$ Jumlah item

Untuk menginterpretasikan grafik IPA, maka grafik IPA dibagi menjadi empat kuadran sebagaimana terlihat pada Gambar 4.1 (Rangkuti, 2003).

\begin{tabular}{c|c|c|}
\cline { 2 - 3 }$y_{i}$ & Prioritas Utama & Pertahankan Prestasi \\
\cline { 2 - 3 } & (I) & (II) \\
\hline $\begin{array}{c}\text { Prioritas Rendah } \\
\text { (III) }\end{array}$ & $\begin{array}{c}\text { Berlebihan } \\
\text { (IV) }\end{array}$ \\
\hline
\end{tabular}

$\bar{x}_{i}$

Gambar 1. Pembagian Kuadran Analisis Kepentingan-Kinerja

\section{Partial Least Squares (PLS)}

$P L S$ digunakan untuk tujuan penelitian kedua dan ketiga. Adapun kriteria-kriteria yang harus dipenuhi untuk analisis ini adalah sebagai berikut.

(1) Evaluasi pengukuran (outer model)

Tabel 2. Evaluasi model pengukuran

\begin{tabular}{lll}
\hline \multicolumn{1}{c}{ Validitas dan Reabilitas } & \multicolumn{1}{c}{ Parameter } & \multicolumn{1}{c}{ Rule of Thumb } \\
\hline Convergent validity & Loading Factor & $>0,5$ (Chin, 1998 dalam Gozali, 2015) \\
\hline Discriminat validity & Cross Loading & $\begin{array}{l}\text { Nilai cross loading yang dituju harus lebih } \\
\text { besar dibandingkan dengan nilai cross } \\
\text { loading dengan konstruk yang lain (Mustafa } \\
\text { dan Wijaya, 2012) }\end{array}$ \\
& & \\
\hline Reabilitas & Composite \\
& Reliability & \\
\hline
\end{tabular}

(2) Evaluasi model struktural (inner model)

Tabel 3. Evaluasi model struktural (inner model)

Kriteria Rule of Thumb

\begin{tabular}{ll}
\hline R-Square & 0,$67 ; 0,33$ dan 0,19 menunjukkan model kuat, moderat dan lemah (Chin, 1998 dalam \\
& Ghozali, 2015). \\
\hline GoF & $\begin{array}{l}\text { Apabila nilai GoF melebihi nilai ambang 0,50, maka dapat dinyatakan model bisa } \\
\text { diterima dan diinterpretasikan (Tenenhaus et al, 2005) }\end{array}$
\end{tabular}




\section{(3) Pengujian hipotesis}

Pengujian hipotesis dilakukan dengan uji statistik $\mathrm{t}$ (t-test). Kalau dalam pengujian ini diperoleh $p$-value $<0,05 ; 0,10$ (alpha 5\%;10\%) atau t statistik $>\mathrm{t}$ tabel, berarti pengujian signifikan, dan sebaliknya kalau $p$-value $>0,05 ; 0,10$ (alpha 5\%;10\%) atau t statistik $<\mathrm{t}$ tabel, berarti tidak signifikan. Bilamana hasil pengujian hipotesis pada outer model signifikan, hal ini menunjukkan bahwa indikator dipandang dapat digunakan sebagai instrumen pengukur variabel laten. Sementara, bilamana hasil pengujian pada inner model adalah signifikan, maka dapat diartikan bahwa terdapat pengaruh yang bermakna variabel laten satu terhadap variabel laten lainnya. (Chin, 1998; Hair et al ,2011; Henseler et al, 2009 dalam Gozali, 2015).

\section{HASIL DAN PEMBAHASAN}

\section{Karakteristik Konsumen}

Dalam penelitian ini karakteristik konsumen diidentifikasi berdasarkan jenis kelamin, usia, pendidikan terakhir, jenis pekerjaan, pendapatan, dan frekuensi berkunjung. Dilihat dari distribusi konsumen berdasarkan jenis kelamin, perbedaan jumlah konsumen antara laki-laki dan perempuan tidak menunjukkan perbedaan yang banyak, dimana dari 100 konsumen, konsumen laki-laki sebanyak 57\% dan perempuan sebanyak $43 \%$. Dilihat dari distribusi konsumen berdasarkan usia, konsumen yang paling banyak berkunjung ke Kopi Made adalah konsumen dengan usia 26 s.d. 35 tahun (50\%), diikuti oleh $<25$ tahun (38\%), dan 36 s.d. 45 tahun (22\%). Tidak ditemukan responden yang berkunjung dengan usia 45 tahun ke atas. Dilihat dari distribusi responden berdasarkan pendidikan terakhir, mayoritas konsumen dengan pndidikan sarjana $(56 \%)$, diikuti oleh pendidikan diploma (37\%), SMA (4\%), dan pascasarjana (3\%). Tidak ditemukan konsumen dengan pendidikan SMP. Dilihat dari distribusi konsumen berdasarkan pekerjaan, mayoritas konsumen Kopi Made bekerja sebagai pegawai swasta (49\%), diikuti oleh wiraswasta $(41 \%)$, pelajar/mahasiswa, ibu rumah tangga dan PNS (2\%). Dilihat dari distribusi konsumen berdasarkan pendapatan per bulan, mayoritas konsumen Kopi Made berpendapatan > 4.000.000 (46\%), diikuti oleh 3.000.000 s.d 3.999 .000 (26\%), 2.000 .000 s.d. 2.999 .000 (20\%), 1.000 .000 s.d. 1.999 .000 (5\%), dan paling sedikit ditemukan konsumen dengan pendapatan <999.000 (3\%). Dilihat dari frekuensi kunjungan konsumen, mayoritas konsumen berkunjung ke Kopi Made sebanyak sekali dalam sebulan (46\%). Sedikit ditemukan responden yang berkunjung sebanyak 4 s.d. 5 kali (8\%), > 7 kali (3\%), dan 6 s.d. 7 kali (2\%).

\section{Tingkat kepuasan konsumen Kopi Made}

Berdasarkan analisis menggunakan Costomer Satisfaction index (CSI), diperoleh tingkat kepuasan konsumen Kopi Made dinyatakan sangat puas dengan nilai $82,72 \%$. Walaupun demikian, masih ada $17,21 \%$ atribut-atribut yang ditawarkan oleh Kopi Made yang belum terpuaskan. Guna menelusuri atribut-atribut yang belum terpuaskan, maka digunakan alat analisis Important Performance Analysis (IPA). Melalui IPA dapat diketehai atribut-atribut yang termasuk dalam kuadran I (prioritas utama untuk diperbaiki), kuadran II (pertahankan prestasi atribut), kuadran III (prioritas rendah untuk diperbaiki), dan kuadran IV (kinerja atribut yang berlebihan). Secara lebih rinci, atribut-atribut yang termasuk kedalam masingmasing kuadran tersebut adalah sebagai berikut.

1. Kuadran I

Atribut-atribut yang termasuk dalam kuadran i, antara lain : variasi produk, pengembangan inovasi produk, manfaat setelah mengkonsumsi produk, dan kebersihan fisik kopi made.

2. Kuadran II

Atribut-atribut yang termasuk dalam kuadran ii, antara lain : ketepatan tata letak meja dan kursi, cita rasa produk, produk diantar sesuai pesanan, kesesuaian harga dengan kualitas, tampilan penyajian makanan, tampilan penyajian minuman, kualitas minuman dan makanan yang ditawarkan, kehandalan pelayanan karyawan yang diberikan dari awal hingga akhir, kemudahan dalam menghubungi karyawan, kecepatan penyajian makanan dan minuman, kehandalan karyawan menyajikan menu, kesigapan karyawan menjawab pertanyaan, kesigapan karyawan menghadapi komplain, kepekaan karyawan terhadap kebutuhan konsumen, kesediaan karyawan melayani konsumen, kesabaran karyawan, keramahan dan kesopanan karyawan, kenyamanan di areal kopi made, dan kopetensi karyawan

3. Kuadran III

Atribut-atribut yang termasuk dalam kuadran iii, antara lain : bentuk arsitektur, tampilan bagian depan, tampilan pintu masuk, tampilan perpaduan warna, kondisi pencahayaan, tampilan plafon, lantunan musik, keleluasaan ruang gerak, kesesuaian dan keindahan gambar, kejelasan tanda petunjuk toilet, kerapihan penampilan karyawan, kemoderenan sarana fisik.

4. Kuadran IV

Atribut-atribut yang termasuk dalam kuadran iv, antara lain : keunikan logo, tampilan peralatan, ketepatan penempatan meja pemesanan dan pembayaran, serta kejelasan tanda petunjuk meja pemesanan dan pembayaran

Variabel-variabel yang Mempengaruhi Kepuasan Konsumen dan Keputusan Pembelian ulang

1. Model pengukuran (outer model) 


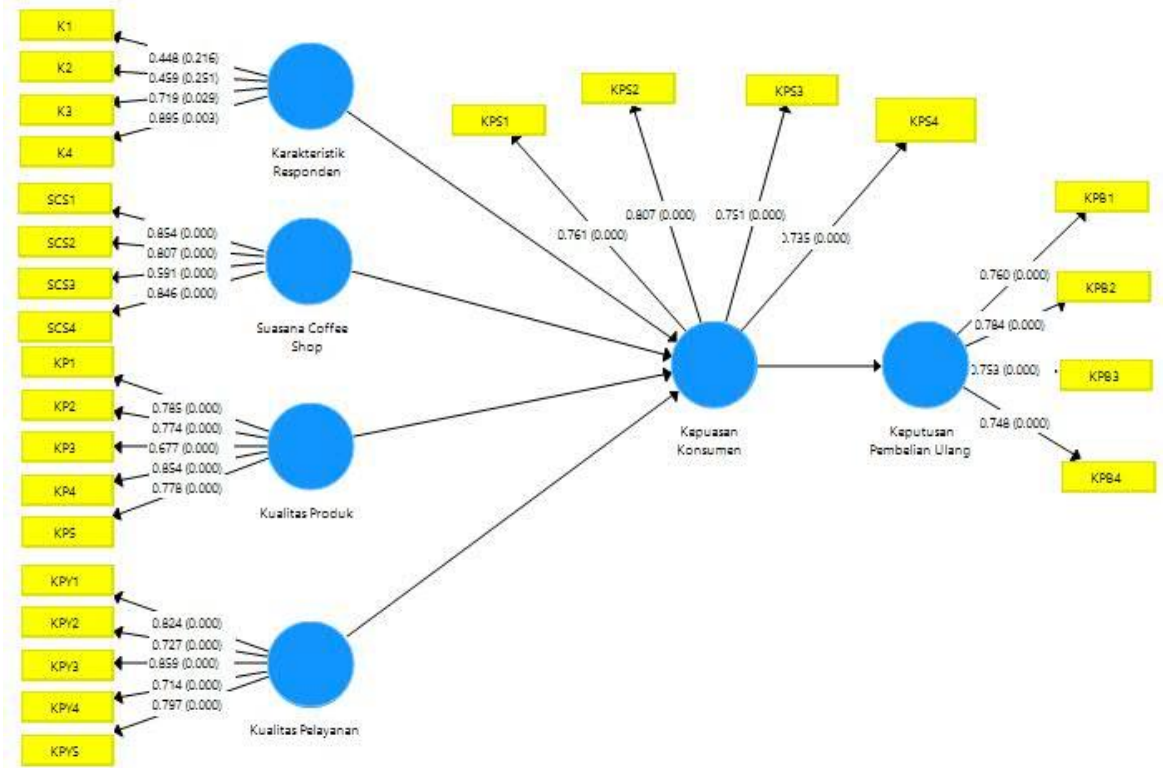

Gambar 2. Model Pengukuran (Outer Model) I

Gambar 2 menunjukkan bahwa indikator umur (K1) dengan nilai loading factor 0,448 dan pendapatan (K2) dengan loading factor 0,459 yang merefleksikan variabel karakteristik konsumen harus dikeluarkan dari model karena memiliki nilai loading factor kurang dari 0,5 dan tidak signifikan (p-value > 0,10). Setelah indikator dikeluarkan, selanjutnya akan dilakukan analisis ulang, sehingga menghasilkan model seperti pada Gambar 3.

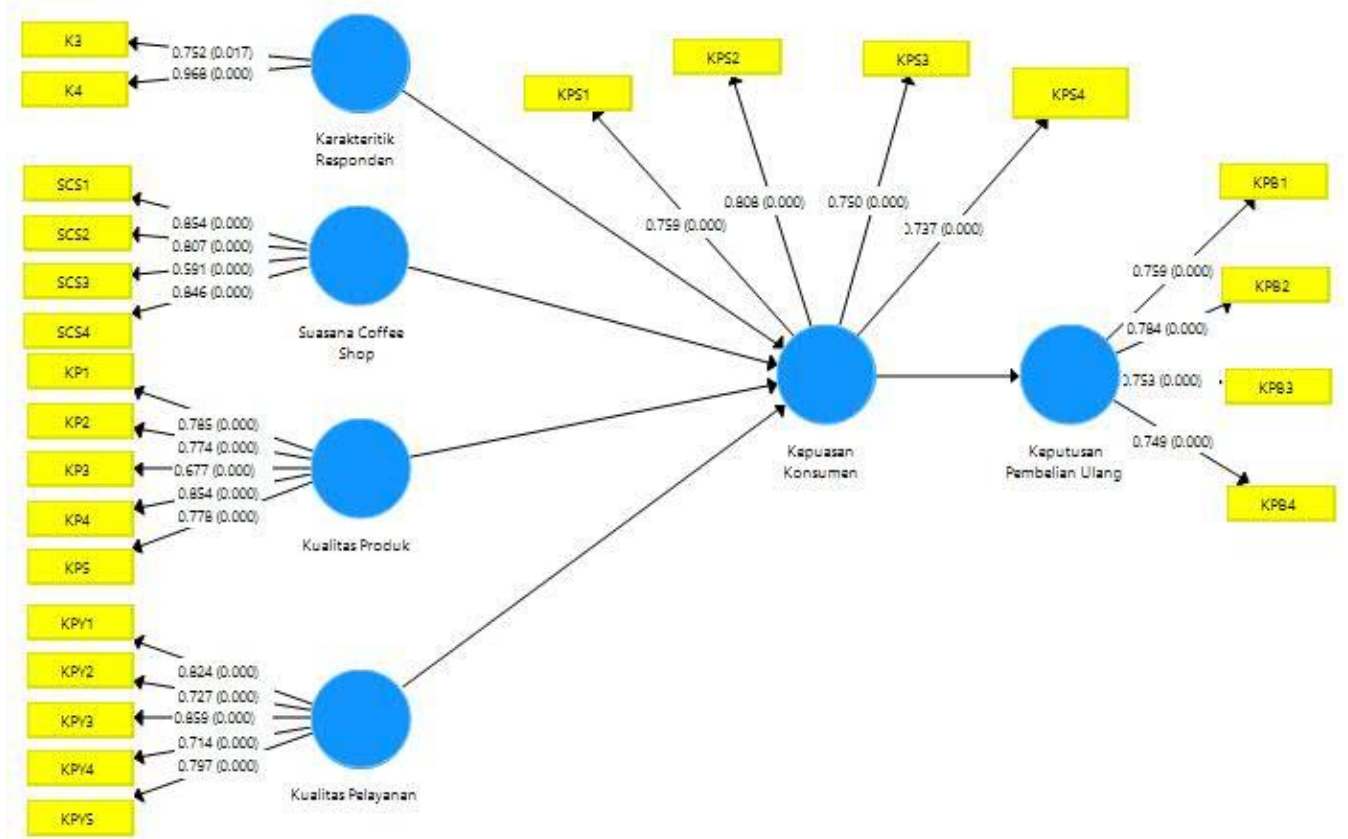

Gambar 3. Model Pengukuran (Outer Model) II

Model pada Gambar 3 menunjukkan bahwa seluruh indikator yang merefleksikan variabel karakteristik konsumen, suasana Kopi Made, kualitas produk, kualitas pelayanan, kepuasan konsumen, dan keputusan pembelian ulang sudah memiliki nilai loading factor $>0,5$ dan nilai $\mathrm{p}$ value $>0,10$, sehingga indikator sudah dinyatakan memenuhi uji convergent validity. Selanjutnya, terdapat uji discriminant validity yang ditunjukkan pada Tabel 4 . Tabel 4 menunjukkan bahwa nilai korelasi antara indiktor dengan variabel konstruknya, baik variabel karakteristik konsumen, suasana Kopi Made, kualitas produk, kualitas pelayanan, kepuasan konsumen, dan keputusan pembelian ulang lebih besar daripada variabel konstruk lainnya 
Tabel 4. Uji Discriminant Validity

\begin{tabular}{|c|c|c|c|c|c|c|}
\hline Indikator & $\begin{array}{c}\text { Karaktersitik } \\
\text { Konsumen }\end{array}$ & $\begin{array}{l}\text { Kepuasan } \\
\text { Konsumen }\end{array}$ & $\begin{array}{c}\text { Keputusan } \\
\text { Pembelian } \\
\text { Ulang }\end{array}$ & $\begin{array}{l}\text { Kualitas } \\
\text { Pelayanan }\end{array}$ & $\begin{array}{l}\text { Kualitas } \\
\text { Produk }\end{array}$ & $\begin{array}{c}\text { Suasana } \\
\text { Kopi } \\
\text { Made }\end{array}$ \\
\hline $\mathrm{K} 3$ & 0.752 & 0.059 & 0.091 & $(0.026)$ & $(0.006)$ & $(0.076)$ \\
\hline K4 & 0.968 & 0.157 & 0.166 & 0.087 & 0.127 & $(0.037)$ \\
\hline KP1 & 0.144 & 0.441 & 0.192 & 0.302 & 0.785 & 0.291 \\
\hline $\mathrm{KP} 2$ & 0.060 & 0.464 & 0.283 & 0.192 & 0.774 & 0.555 \\
\hline KP3 & 0.089 & 0.426 & 0.241 & 0.202 & 0.677 & 0.277 \\
\hline KP4 & 0.092 & 0.541 & 0.268 & 0.340 & 0.854 & 0.353 \\
\hline KP5 & 0.007 & 0.481 & 0.252 & 0.383 & 0.778 & 0.405 \\
\hline KPB1 & 0.124 & 0.467 & 0.759 & 0.114 & 0.332 & 0.284 \\
\hline KPB2 & 0.139 & 0.485 & 0.784 & 0.226 & 0.273 & 0.385 \\
\hline KPB3 & 0.065 & 0.364 & 0.753 & $(0.003)$ & 0.207 & 0.130 \\
\hline KPB4 & 0.148 & 0.470 & 0.749 & 0.096 & 0.154 & 0.169 \\
\hline KPS1 & 0.124 & 0.759 & 0.434 & 0.360 & 0.444 & 0.546 \\
\hline KPS2 & 0.046 & 0.808 & 0.429 & 0.352 & 0.548 & 0.560 \\
\hline KPS3 & 0.158 & 0.750 & 0.412 & 0.359 & 0.421 & 0.370 \\
\hline KPS4 & 0.122 & 0.737 & 0.470 & 0.321 & 0.438 & 0.395 \\
\hline KPY1 & 0.047 & 0.422 & 0.121 & 0.824 & 0.323 & 0.368 \\
\hline KPY2 & 0.043 & 0.219 & 0.036 & 0.727 & 0.313 & 0.209 \\
\hline KPY3 & 0.038 & 0.432 & 0.140 & 0.859 & 0.318 & 0.457 \\
\hline KPY4 & 0.070 & 0.287 & 0.130 & 0.714 & 0.147 & 0.238 \\
\hline KPY5 & 0.051 & 0.355 & 0.143 & 0.797 & 0.340 & 0.384 \\
\hline SCS1 & $(0.114)$ & 0.600 & 0.325 & 0.419 & 0.470 & 0.854 \\
\hline $\mathrm{SCS} 2$ & 0.055 & 0.463 & 0.171 & 0.507 & 0.438 & 0.807 \\
\hline SCS3 & $(0.037)$ & 0.386 & 0.282 & 0.151 & 0.183 & 0.591 \\
\hline SCS4 & $(0.046)$ & 0.451 & 0.238 & 0.290 & 0.383 & 0.846 \\
\hline
\end{tabular}

Selanjutnya terdapat uji model pengukuran melalui composite reability yang ditunjukkan pada Tabel 5 .

Tabel 5. Uji Model Pengukuran melalui Composite Reability

\begin{tabular}{llcc}
\hline \multicolumn{1}{c}{ Variabel Laten } & Jenis Variabel & $\begin{array}{c}\text { Jumlah } \\
\text { Indikator }\end{array}$ & $\begin{array}{c}\text { Composite } \\
\text { Reliability } \\
\text { (CR) }\end{array}$ \\
\hline Karakteristik konsumen & Eksogenus & 2 & 0.856 \\
Suasana Kopi Made & Eksogenus & 4 & 0.861 \\
Kualitas produk & Eksogenus & 5 & 0.882 \\
Kualitas pelayanan & Eksogenus & 5 & 0.890 \\
Kepuasan konsumen & Eksogenus/ & 4 & 0.849 \\
Keputusan pembelian ulang & Endogenus & 4 & 0.847 \\
\hline
\end{tabular}

Tabel 5 menunjukkan bahwa seluruh variabel laten memiliki nilai composite reability lebih besar dari 0,6 yang berarti seluruh indikator pada masingmasing variabel laten (kakteristik konsumen, suasana Kopi Made, kualitas produk, kualitas pelayanan, kepuasan konsumen, dan keputusan pembelian ulang) memiliki konsistensi internal yang bisa diandalkan. 


\section{Model struktural}

Sebelum dilakukan interpretasi terhadap hasil analisis model persamaan struktural penelitian ini, beberapa peneliti Fornell \& Larcker (1981), Chin et al. (2003), Hair et al. (2012), Henseler et al (2009) dalam Suryawardani (2018) merekomendasikan agar kelayakan model diperiksa. Tabel 6 memperlihatkan ukuran-ukuran yang lazim digunakan untuk menilai kelayakan model persamaan struktural yang dianalisis dengan metode SmartPLS.

Tabel 6. Uji Model Struktural

\begin{tabular}{|c|c|c|c|c|}
\hline Variabel Laten & Jenis Variabel & $\begin{array}{l}\text { Jumlah } \\
\text { Indikator }\end{array}$ & $\begin{array}{c}\text { Average } \\
\text { Variance } \\
\text { Extracted } \\
\text { (AVE) }\end{array}$ & $\mathrm{R} 2$ \\
\hline Karakteristik konsumen & Eksogenus & 2 & 0.751 & $\mathrm{NA}^{\mathrm{a}}$ \\
\hline Suasana Kopi Made & Eksogenus & 4 & 0.611 & $\mathrm{NA}^{\mathrm{a}}$ \\
\hline Kualitas produk & Eksogenus & 5 & 0.601 & $\mathrm{NA}^{\mathrm{a}}$ \\
\hline Kualitas pelayanan & Eksogenus & 5 & 0.618 & $\mathrm{NA}^{\mathrm{a}}$ \\
\hline Kepuasan konsumen & $\begin{array}{l}\text { Eksogenus/ } \\
\text { Endogenus }\end{array}$ & 4 & 0.584 & 0.539 \\
\hline Keputusan pembelian ulang & Endogenus & 4 & 0.580 & 0.351 \\
\hline Rata-Rata & & & $0.612^{\mathrm{b}}$ & 0.445 \\
\hline Gof & 0,522 & & & \\
\hline
\end{tabular}

Tabel 6 menunjukkan bahwa nilai koefisien determinasi $\left(\mathrm{R}^{2}\right)$ kepuasan konsumen dan keputusan pembelian ulang masing-masing sebesar 0,539 dan 0,351 yang artinya kemampuan dari variabel karakteristik konsumen, suasana coffee shop, kualitas produk, dan kualitas pelayanan dalam menjelaskan keragaman dari kepuasan konsumen sebesar 53,9\% dan kemampuan variabel kepuasan konsumen dalam menjelaskan keragaman dari keputusan pembelian ulang sebesar $35,1 \%$. Kedua variabel laten endogenus ini terjelaskan secara moderat. Hasil ini merujuk pada Chin et al. (2003) yang menyatakan variabel laten endogenus dengan nilai $\mathrm{R}^{2}$ berada pada rentang nilai 0.19 hingga 0.33 dikategorikan laten yang dijelaskan secara lemah (weakly explained); berada pada rentang 0.33 hingga 0.67 dikategorikan laten yang dijelaskan secara moderat; dan di atas nilai 0.67 dikategorikan terjelaskan secara kuat (substantially explained). Selain itu, Tabel 6 juga menunjukkan nilai GoF dari model sebesar 0.522 , sebuah ukuran yang melebihi nilai ambang 0.50 untuk menyatakan model bisa diterima dan interpretasi analisis bisa dilanjutkan. Kriteria GoF ini merujuk pada formula yang diperkenalkan oleh Tenenhaus et al. (2005).

Tabel 7. Pengaruh Langsung Variabel Eksogenus terhadap Variabel Endogenus

\begin{tabular}{llcccc}
\hline \multicolumn{1}{c}{ Var. Eksogenus } & \multicolumn{1}{c}{ Var. Endogenus } & Koefisien & $\begin{array}{c}\text { Standar } \\
\text { Deviasi }\end{array}$ & T-Statistik \\
\hline Karakteristik konsumen & $\Rightarrow$ & Kps. Konsumen & 0.119 & 0.085 & $1.407 \mathrm{~ns}$ \\
Suasana Kopi Made & & Kps. Konsumen & 0.389 & 0.096 & $4.032^{* *}$ \\
Kualitas produk & $\Rightarrow$ Kps.Konsumen & 0.357 & 0.082 & $4.335^{* *}$ \\
Kualitas pelayanan & $\Rightarrow$ Kps. Konsumen & 0.140 & 0.080 & $1.761^{*}$ \\
Kepuasan konsumen & $\Rightarrow$ Kpb. Ulang & 0.593 & 0.075 & $7944^{* *}$ \\
\hline
\end{tabular}

Keterangan :

$$
\begin{array}{ll}
\text { ns } & : \text { tidak signifikan } \\
* * & : \text { signifikan pada taraf uji } 1 \%(\mathrm{t} \text { hitung }>2,58 \\
* & : \text { signifikan pada taraf uji } 10 \%(\mathrm{t} \text { hitung }>1,65)
\end{array}
$$

Tabel 7 menunjukkan bahwa variabel-variabel yang berpengaruh signifikan terhadap kepuasan konsumen adalah suasana Kopi Made, kualitas produk, dan kualitas pelayanan dengan besar pengaruh secara berturut-turut sebesar 0,$389 ; 0,357$; dan 0,140 . Ketiga variabel tersebut memberikan pengaruh yang posiif, artinya semakin baik suasana Kopi Made, kualitas produk, dan kualitas pelayanan yang diberikan maka kepuasan konsumen akan semakin tinggi. Pengaruh terbesar diberikan oleh variabel suasana Kopi Made. Hal ini sejalan dengan penelitian yang dilakukan oleh Fajriah (2015); Yesenia (2014); dan Sasongko dan Subagio (2013). Disisi lain, variabel karakteristik konsumen tidak berpengaruh signifikan terhadap kepuasan konsumen. Tabel 7 juga menunjukkan bahwa kepuasan konsumen berpengaruh secara signifikan terhadap keputusan pembelian ulang dengan pengaruh sebesar 0,593, artinya semakin puas konsumen maka konsumen akan semakin berniat untuk melakukan pembelian ulang. Hasi ini sejalan dengan penelitian yang dilakukan oleh Noviar 
(2015). perilaku pembelian ulang itu berhubungan erat dengan konsep dari brand loyalty. Loyalty merupakan umpan balik yang menyenangkan terhadap merek, produk, tempat yang ditunjukkan dengan konsisten pembelian produk setiap saat (Sutisna, 2003 dalan Ustriana, 2016). Hasil ini merupakan pengaruh langsung antara variabel eksogenus terhadap variabel endogenus. Selanjutnya akan dilihat pengaruh tak langsung antara variabel eksogenus terhadap variabel endogenus yang ditunjukkan pada Tabel 8 berikut.

Tabel 8. Pengaruh tak langusng variabel eksogenus terhadap variabel endogenus

\begin{tabular}{|c|c|c|c|c|c|c|}
\hline \multicolumn{4}{|c|}{ Variabel } & \multirow{2}{*}{ Koefisien } & \multirow{2}{*}{$\begin{array}{l}\text { St. } \\
\text { Dev }\end{array}$} & \multirow{2}{*}{$\begin{array}{c}\mathrm{T}- \\
\text { Statistik }\end{array}$} \\
\hline Eksogenus & & Mediasi & Endogenus & & & \\
\hline Karakteristik konsumen & $\Rightarrow$ & Kepuasan & $\Rightarrow \begin{array}{l}\text { Keputusan } \\
\text { pembelian ulang }\end{array}$ & 0.071 & 0.053 & $1.338 \mathrm{~ns}$ \\
\hline Suasana Kopi Made & $\Rightarrow$ & Kepuasan & $\Rightarrow \begin{array}{l}\text { Keputusan } \\
\text { pembelian ulang }\end{array}$ & 0.230 & 0.065 & $3.558 * *$ \\
\hline Kualitas produk & $\Rightarrow$ & Kepuasan & $\Rightarrow \begin{array}{l}\text { Keputusan } \\
\text { pembelian ulang }\end{array}$ & 0.212 & 0.056 & $3.758^{* *}$ \\
\hline Kualitas pelayanan & $\Rightarrow$ & Kepuasan & $\Rightarrow \begin{array}{l}\text { Keputusan } \\
\text { pembelian ulang }\end{array}$ & 0.083 & 0.049 & $1.683^{* *}$ \\
\hline \multicolumn{7}{|l|}{ erangan } \\
\hline $\begin{array}{l}\text { : tidak signifikan } \\
\text { : signifikan pada tar } \\
\text { : signifikan pada tar }\end{array}$ & 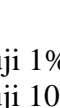 & $\begin{array}{l}\text { (t hitung }> \\
\text { (t hitung }\end{array}$ & $\begin{array}{l}2,58 \\
>1,65)\end{array}$ & & & \\
\hline
\end{tabular}

Tabel 8 menunjukkan bahwa Tiga pengaruh tak langsung masing-masing pengaruh tak langsung suasana Kopi Made, kualitas produk dan kualitas pelayanan terhadap keputusan pembelian ulang, melalui mediasi variabel laten kepuasan konsumen, menunjukkan pengaruh yang signifikan dengan koefisien jalur sebesar $0.230,0,212$, dan 0.083 ; sedangkan pengaruh tak langsung karakteristik konsumen terhadap keputusan pembelian ulang tidak menunjukkan pengaruh yang signifikan.

Kombinasi pengaruh langsung dengan pengaruh tak langsung membentuk pengaruh total sebuah laten eksogenus terhadap laten endogenus. Tabel 9 menunjukkan pengaruh total dari hubungan antarvariabel pada model penelitian:

Tabel 9. Pengaruh Total Variabel Eksogenus terhadap Variabel Endogenus

\begin{tabular}{|c|c|c|c|c|c|}
\hline Variabel eksogenus & $\Rightarrow$ & Variabel endogenus & Koefisien & St. Dev & $\begin{array}{c}\mathrm{T}- \\
\text { Statistik }\end{array}$ \\
\hline Karakteristik konsumen & $\Rightarrow$ & Kepuasan konsumen & 0.119 & 0.085 & $1.407 \mathrm{~ns}$ \\
\hline Karakteristik konsumen & $\Rightarrow$ & Keputusan pembelian ulang & 0.071 & 0.053 & $1.338 \mathrm{~ns}$ \\
\hline Kepuasan Konsumen & $\Rightarrow$ & Keputusan pembelian ulang & 0.593 & 0.075 & $7.944 * *$ \\
\hline Suasana Kopi Made & $\Rightarrow$ & Kepuasan konsumen & 0.389 & 0.096 & $4.032 * *$ \\
\hline Suasana Kopi Made & $\Rightarrow$ & Keputusan pembelian ulang & 0.230 & 0.065 & $3.558 * *$ \\
\hline Kualitas Produk & $\Rightarrow$ & Kepuasan konsumen & 0.357 & 0.082 & $4.335 * *$ \\
\hline Kualitas produk & $\Rightarrow$ & Keputusan pembelian ulang & 0.212 & 0.056 & $3.758 * *$ \\
\hline Kualitas Pelayanan & $\Rightarrow$ & Kepuasan Konsumen & 0.14 & 0.08 & $1.761 *$ \\
\hline Kualitas pelayanan & $\Rightarrow$ & Keputusan Pembelian Ulang & 0.083 & 0.049 & $1.683^{*}$ \\
\hline
\end{tabular}

\section{Keterangan :}

ns : tidak signifikan

** : signifikan pada taraf uji $1 \%$ (t hitung $>2,58$

* $\quad$ : signifikan pada taraf uji $10 \%$ (t hitung $>1,65$ )

\section{SIMPULAN DAN SARAN}

\section{Simpulan}

Berdasarkan hasil analisis data dan pembahasan maka dapat disimpulkan tingkat kepuasan konsumen kopi made terhadap atributatribut yang di kopi made dinyatakan sangat puas dengan nilai sebesar $82,79 \%$. Hal ini menunjukkan bahwa sebagian besar kinerja yang diberikan oleh Kopi Made sudah sesuai dengan harapan
konsumen.Variabel-variabel yang berpengaruh signifikan terhadap kepuasan konsumen adalah suasana kopi made, kualitas produk, dan kualitas pelayanan. Ketiga variabel tersebut memberikan pengaruh yang positif. Pengaruh tertinggi diberikan oleh suasana coffee shop dengan pengaruh sebesar 0,389 . Variabel karakteristik konsumen tidak berpengaruh signifikan terhadap kepuasan konsumen. Kepuasan konsumen di kopi made 
berpengaruh signifikan terhadap keputusan pembelian ulang dengan pengaruh sebesar 0,593.

\section{Saran}

Saran yang dapat disampaikan berhubungan dengan penelitian ini adalah Kopi Made perlu memperbaiki atribut-atribut yang menjadi prioritas perbaikan utama yang dirasa belum baik, seperti variasi produk Kopi Made, pengembangan inovasi produk, manfaat yang diperoleh setelah mengkonsumsi produk, dan kebersihan fisik Kopi Made. Mengingat variabel suasana Kopi Made, kualitas produk, dan kualitas pelayan berpengaruh terhadap kepuasan konsumen, dan pengaruh terbesar diberikan oleh Suasana Kopi Made, maka seluruh atribut yang terdapat pada Suasana Kopi Made menjadi perhatian utama untuk dipertahankan dan ditingkatkan kualitasnya. Meskipun demikan, atribut-atribut pada kualitas produk dan kualitas pelayanan tetap kualitasnya tetap dipertahankan. Diperlukan penelitian lanjutan terkait variabel yang digunakan, seperti pengaruh 7P pemasaran terhadap kepuasan konsumen di Kopi Made.

\section{DAFTAR PUSTAKA}

Fajriah, S. 2015. "Pengaruh Store Atmosphere dan Dimensi Kualitas Produk Terhadap Kepuasan Konsumen di Waroeng Taman, Bogor". (Skripsi). Bogor: Institut Pertanian Bogor.

Ghozali, I. 2015. Structural Equation Modeling Metode Alternatif dengan Partial Least Square. Edisi 2. Semarang: Universitas Diponegoro.

Maima, 2012. “Analisis Pengaruh Kepercayaan Pelanggan Dan Kualitas Pelayanan Terhadap Sikap Pelanggan Dan Implikasinya Terhadap Keputusan Pembelian Ulang (Studi Kasus Pada Cv. Mukti Manunggal Semarang)". (Skripsi). Semarang: Universitas Diponegoro.

Mustafa dan Wijaya. 2012. Panduan Teknik Statistik SEM \& PLS dengan SPSS AMOS. Yogyakarta : Cahaya Atma Pustaka

Pramono, J., I K.B. Susrusa, and A.S. Wiranatha. 2014. Environmental Management at Star Rated Hotel in Bali. E-Journal of Tourism Vol.1. No.1. (2014). Page: 57-68. ISSN: 2407-392X.

Rangkuti, F. 2003. Measuring Customer Satisfaction. Cetakan Kedua. Jakarta : Penerbit PT. Gramedia Pustaka Utama.

Supranto. 2001. Pengukuran Tingkat Kepuasan Pelanggan untuk Menaikkan Pangsa Pasar. Jakarta : Penerbit Rineka Cipta 230,243.

Sasongko, F dan Subagio. 2013. "Pengaruh Kualitas Layanan Terhadap Kepuasan Pelanggan Restoran Ayam Penyet Ria”. Jurnal
Manajemen Pemasaran Petra

Universitas Kristen Petra, Surabaya. Vol 1. No.1.

Suryawardani, I G.A.O., and A.S. Wiranatha. 2015. Destination Marketing Strategy in Bali through Optimizing the Potential of Local Products. E-Journal of Tourism. Vol.1. No.1. (2014). Page: 35-49. ISSN: 2407$392 X$.

Suryawardani, I G.A.O., and A.S. Wiranatha. 2016. Assessment of Guests' Perception in Implementation of Green Hotel in Supporting Sustainable Tourism. EJournal of Tourism Vol.3. No.1. (2016). Page: 21-32. ISSN: 2407-392.

Suryawardani, I G.A.O., A.S. Wiranatha, 1 K.G. Bendesa, M. Antara and Maria GravariBarbass. 2017. A Structural Model of Foreign Tourists' Loyalty in Nature-based Tourism in Bali. International Journal of Applied Business and Economic Research, Vol. 15, Number 9. 2018, page 195-215 (2017). ISSN 0972-7302.

Suryawardani, I G.A.O. 2018. Evaluation of Marketing Strategy of Sanur Village Festival Baesd on Visitors' Behaviour. International Journal of Applied Business and Economic Research, Vol. 16 Number 2, 2018, page 216-276. ISSN 0972-7302.

Tenenhaus, M., Vinzi, V.E., Chatelin, Y.-M. \& Lauro, C., 2005. PLS path modeling. Computational Statistics \& Data Analysis, 48, pp.159-205.

Ustriyana, I.Nyoman Gede. 2015. "Urban Development and Its Impact On Agriculture Lands. (series online). [diakses pada tanggal 8 Agustus 2018]. Available from: URL: http://citeseerx.ist.psu.edu/viewdoc/downl oad?doi=10.1.1.740.2778\&rep=rep1\&typ $\underline{\mathrm{e}=\mathrm{pdf}}$

Ustriyana, I.Nyoman Gede. 2016. "Factors Shaping the Image of Badung Tradisional Market in Denpasar City, Bali Province". International Journal of Environment, Agriculture and Biotechnology (UEAB). Vol-1, Issue 4.

Wiranatha, A.S. 2015. Sustainable Development Strategy for Ecotourism at Tangkahan, North Sumatera. E-Journal of Tourism Vol.2. No.1. (2015). Page:1-8. ISSN: 2407-392X.

Wiranatha, A.S., I G.A.O., Suryawardani, 1 K.G. Bendesa and M. Antara. 2016. Model of Foreign tourist's Loyalty on Marine Tourism to Visit Bali. Internasional Journal of Multidisciplinary Educational Research, Volume 5, Issue 3 (2), 2016.

Medikana, et al., Variabel..|40 
Wiranatha, A.S., I G.A.O. Suryawardani, and 1 K.G. Bendesa. 2018. Model of Foreign Tourist' Loyalty in Cultural and Heritage Tourism. Journal of Global Stochastics Analysis.

Wiranatha, A.S., and I G.A.O. Suryawardani. 2018. A Structural Model of Community Based Agrotourism Development at The World Heritage Site of Jatiluwih Rice Field Terrace in Tabanan, Bali. Journal of Global
Stochastics Analysis, Vol. 5 Number 7 (2018), page; 65-81. ISSN: 2248-94444.

Yesenia. 2014. "Pengaruh Kualitas Pelayanan Dan Produk Terhadap Kepuasan Serta Loyalitas Pelanggan KFC di Tangerang Selatan". (Skripsi). Bogor: Institut Pertanian Bogor. 